\title{
STUDY OF INCIDENCE, ACCURACY OF FNAC AND SURGICAL MANAGEMENT OF PAROTID SWELLINGS
}

\author{
Bakthavatsalam Sathyapriya ${ }^{1}$, Anandi Andappan ${ }^{2}$
}

${ }^{1}$ Associate Professor, Department of General Surgery, Government Thoothukudi Medical College.

${ }^{2}$ Associate Professor, Department of General Surgery, Government Thoothukudi Medical College.

\section{ABSTRACT}

\section{BACKGROUND}

Parotid swellings are the commonest one in salivary gland tumours. My study includes incidence, accuracy of FNAC, various surgical modalities of treatment and post-operative complications and comparison with world statistics.

\section{METHODS}

The cohort study which included 45 patients was conducted in Madras Medical College Hospital. Data was collected from the patients after obtaining their consent. The age group ranged from 16 years to 77 years. FNAC was performed in all patients. Inclusion criteria were patients with parotid swellings. Exclusion criteria were patients with parotid lesions due to systemic or metabolic illness.

\section{CONCLUSION}

1. Parotid lesions comprised of the most common salivary gland lesion in our hospital.

2. Amongst the various lesions it was noted that benign tumours were the most common and the least common were nonneoplastic disorders.

3. The sex incidence showed a similar distribution among both males and females with the ratio being 1:1.02.

4. FNAC correlated in a total of $86.67 \%$ of cases.

5. Most commonly performed surgery was superficial parotidectomy.

6. Facial nerve palsy and seroma formation were the commonest complication noted post-operatively.

\section{KEYWORDS}

Parotid Tumours, FNAC, Superficial Parotidectomy, Facial Nerve.

HOW TO CITE THIS ARTICLE: Sathyapriya B, Andappan A. Study of incidence, accuracy of FNAC and surgical management of parotid swellings. J. Evolution Med. Dent. Sci. 2016;5(28):1461-1465, DOI: 10.14260/jemds/2016/343

\section{INTRODUCTION}

1. To study the incidence of various parotid swelling.

2. To discuss accuracy of FNAC in comparison to the histopathological reports.

3. To study the various surgical modalities of treatment of parotid swellings.

4. To discuss the postoperative complications and comparison with world statistics.

\section{MATERIALS AND METHODS}

The cohort study which included 45 patients was conducted in Madras Medical College Hospital. Data was collected from the patients after obtaining their consent. ${ }^{1}$ In the group, a total of 19 males and 26 females were present. The age group ranged from 16 years to 77 years. FNAC was performed in all patients. Histopathology of specimens was done in 41 cases. A total of 7 non-neoplastic, 22 benign and 16 malignant lesions were identified; 41 patients were operated on and postoperative radiotherapy was given in 10 cases.

Financial or Other, Competing Interest: None.

Submission 18-02-2016, Peer Review 12-03-2016,

Acceptance 19-03-2016, Published 07-04-2016.

Corresponding Author:

Dr. Bakthavatsalam Sathyapriya,

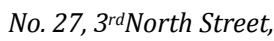

Kennedy Square,

Sembium.

Chennai-600011.

E-mail: drbspriya@yahoo.co.in

DOI: $10.14260 /$ jemds $/ 2016 / 343$
Inclusion criteria were patients with parotid swellings. Exclusion criteria were patients with parotid lesions due to systemic or metabolic illness.

\section{Observation and Analysis}

The observation of the study of 45 parotid lesions yielded the following results. ${ }^{2}$

\begin{tabular}{|c|c|c|}
\hline Lesion & $\begin{array}{c}\text { Total } \\
\text { No. of Cases }\end{array}$ & Percentage \\
\hline Non-Neoplastic & 7 & $15.55 \%$ \\
\hline Benign & 22 & $48.89 \%$ \\
\hline Malignant & 16 & $35.56 \%$ \\
\hline \multicolumn{2}{|c|}{ Overall Incidence } \\
\hline
\end{tabular}

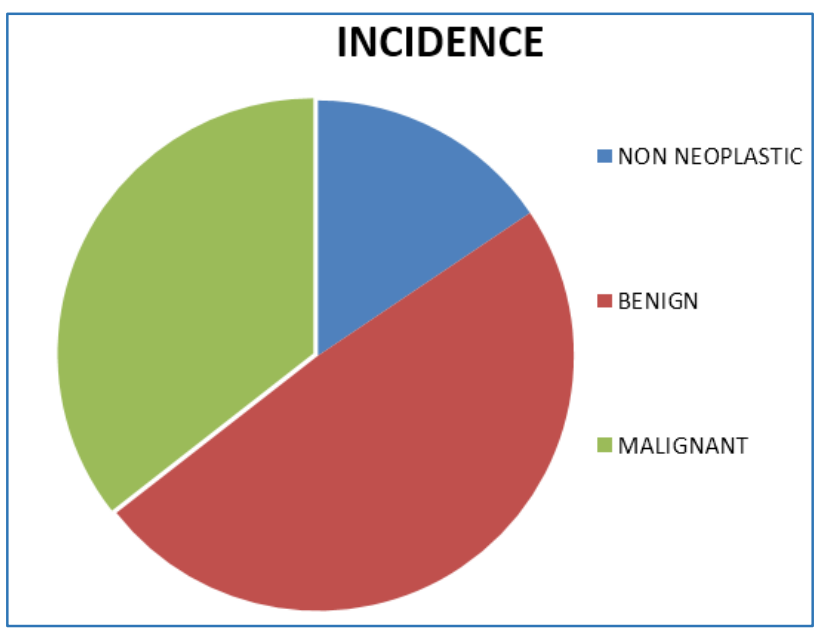




\begin{tabular}{|c|c|c|c|}
\hline & Male & Female & Total \\
\hline Non-Neoplastic & $4.44 \%$ & $11.11 \%$ & $15.56 \%$ \\
\hline Benign & $22.22 \%$ & $26.67 \%$ & $48.89 \%$ \\
\hline Malignant & $17.78 \%$ & $17.78 \%$ & $35.56 \%$ \\
\hline \multicolumn{3}{|c|}{ Sex Incidence Distribution } \\
\hline
\end{tabular}

\begin{tabular}{|c|c|c|}
\hline Age Group & No. of Cases & Percentage \\
\hline $10-19$ & 3 & $6.66 \%$ \\
\hline $20-29$ & 5 & $11.11 \%$ \\
\hline $30-39$ & 9 & $19.98 \%$ \\
\hline $40-49$ & 7 & $15.54 \%$ \\
\hline $50-59$ & 7 & $15.54 \%$ \\
\hline $60-69$ & 9 & $19.98 \%$ \\
\hline $70-79$ & 5 & $11.11 \%$ \\
\hline \multicolumn{3}{|c|}{ Age Incidence } \\
\hline
\end{tabular}

Analysis of Individual Groups of Lesions Yielded the Following

RESULTS

A) Non-Neoplastic Lesion

\begin{tabular}{|c|c|c|}
\hline Lesion & Male & Female \\
\hline Chronic sialadenitis & - & 1 \\
\hline Abscess & 1 & 3 \\
\hline Cystic lesion & 1 & - \\
\hline Reactive adenitis & - & 1 \\
\hline \multicolumn{2}{|c|}{ Non-Neoplastic Lesion } \\
\hline
\end{tabular}

Abscess formed a majority of the non-neoplastic group with 4 out of 7 cases.

\begin{tabular}{|c|c|c|c|}
\hline Sex & No. of Cases & Percentage & $\begin{array}{c}\text { Overall } \\
\text { Percentage }\end{array}$ \\
\hline MALE & 2 & $28.57 \%$ & $4.44 \%$ \\
\hline FEMALE & 5 & $71.43 \%$ & $11.11 \%$ \\
\hline \multicolumn{3}{|c|}{ Sex Incidence } \\
\hline
\end{tabular}

Women were more affected by non-neoplastic parotid lesions than men having $71.43 \%$ of the lesions. ${ }^{3}$

\section{FNAC}

In the cytological analysis, it was noted that though there was a higher rate of lesions which were positive the true positives were lesser. 4,5

\begin{tabular}{|c|c|c|}
\hline Lesion & Positive FNAC & Accuracy \\
\hline Chronic sialadenitis & 2 & $50 \%$ \\
\hline Abscess & 5 & $100 \%$ \\
\hline Cystic lesions & 2 & $50 \%$ \\
\hline Reactive adenitis & 1 & $100 \%$ \\
\hline \multicolumn{3}{|c|}{ FNAC } \\
\hline
\end{tabular}

On further evaluation, 3 lesions turned out to be nonHodgkin's lymphoma, mucoepidermoid carcinoma and pleomorphic adenoma. Hence, the overall accuracy of FNAC is around $30 \%{ }^{6}$

In the data set of our study, it was found to be highly sensitive and specific. Positive predictive value of the $77 \%$ was found with this data. ${ }^{7}$

\begin{tabular}{|c|c|c|}
\hline Presentation & No. of Patients & Percentage \\
\hline Painful swelling & 1 & $14.29 \%$ \\
\hline Painless swelling & 6 & $85.71 \%$ \\
\hline Discharge & Nil & --- \\
\hline Facial nerve palsy & Nil & --- \\
\hline Node enlargement & Nil & --- \\
\hline \multicolumn{3}{|c|}{ Presentation } \\
\hline
\end{tabular}

\begin{tabular}{|c|c|c|}
\hline Treatment & Percentage & $\begin{array}{c}\text { Overall } \\
\text { \% }\end{array}$ \\
\hline Incision and drainage & $42.86 \%$ & $6.66 \%$ \\
\hline Superficial parotidectomy & $57.14 \%$ & $8.88 \%$ \\
\hline \multicolumn{2}{|c|}{ Treatment } \\
\hline
\end{tabular}

\section{COMPLICATIONS}

Significant complications noted in this was seen only in one case where seroma and parotid fistula developed. This resolved on its own with time and consecutive medial management.

\section{B). Neoplastic Lesions \\ Benign Lesions}

It was seen that among the benign lesions, pleomorphic adenoma was a dominant lesion. A total of 22 benign neoplasms were present in the study, which comprised of $48.88 \%$ of all lesions in the study. ${ }^{8}$

\begin{tabular}{|c|c|c|c|}
\hline Lesion & No. of Cases & $\mathbf{\%}$ & $\begin{array}{c}\text { Overall } \\
\mathbf{\%}\end{array}$ \\
\hline Pleomorphic Adenoma & 20 & $90.9 \%$ & $44.44 \%$ \\
\hline Warthin's tumour & 1 & $4.55 \%$ & $2.22 \%$ \\
\hline Lipoma & 1 & $4.55 \%$ & $2.22 \%$ \\
\hline \multicolumn{3}{|c|}{ Lesion Incidence } \\
\hline
\end{tabular}

\begin{tabular}{|c|c|c|c|}
\hline Sex & No. of Cases & \% & Overall \% \\
\hline Male & 10 & $45.45 \%$ & $22.22 \%$ \\
\hline Female & 12 & $54.55 \%$ & $26.66 \%$ \\
\hline \multicolumn{4}{|c|}{ Sex Incidence } \\
\hline
\end{tabular}

In this category it was seen that though the incidence was marginally more among females, males too were maximum affected by benign lesions. ${ }^{9}$

\begin{tabular}{|c|c|c|}
\hline Age Group & No. of Patients & Percentage \\
\hline $10-19$ & 1 & $2.22 \%$ \\
\hline $20-29$ & 2 & $4.44 \%$ \\
\hline $30-39$ & 6 & $13.33 \%$ \\
\hline $40-49$ & 4 & $8.88 \%$ \\
\hline $50-59$ & 4 & $8.88 \%$ \\
\hline $60-69$ & 4 & $8.88 \%$ \\
\hline $70-79$ & 1 & $2.22 \%$ \\
\hline \multicolumn{3}{|c|}{ Age Incidence } \\
\hline
\end{tabular}

Therefore, the age group most susceptible to benign lesions is in the $4^{\text {th }}$ decade. The youngest patient seen was a 16-year-old male with a lipoma.

\begin{tabular}{|c|c|}
\hline Lesion & Total No. Detected \\
\hline Pleomorphic Adenoma & 19 \\
\hline Warthin's tumour & 1 \\
\hline Lipoma & 1 \\
\hline \multicolumn{2}{|c|}{ FNAC } \\
\hline
\end{tabular}

In one patient, FNAC showed a cystic aspirate when it was actually a pleomorphic adenoma.

\section{Treatment}

Surgery was the mainstay treatment of the benign lesions. Most underwent superficial parotidectomy barring the case of lipoma who underwent excision of the lesion alone. ${ }^{10}$ 


\begin{tabular}{|c|c|c|c|}
\hline Surgery & $\begin{array}{c}\text { No. of } \\
\text { Cases }\end{array}$ & $\begin{array}{c}\text { Percentage } \\
\text { Overall }\end{array}$ & Percentage \\
\hline $\begin{array}{c}\text { Superficial } \\
\text { Parotidectomy }\end{array}$ & 21 & $46.67 \%$ & $95.45 \%$ \\
\hline Excision & 1 & $2.22 \%$ & $4.55 \%$ \\
\hline \multicolumn{4}{|c|}{ Treatment } \\
\hline
\end{tabular}

\begin{tabular}{|c|c|c|}
\hline Complications & No. of Patients & Percentage \\
\hline Seroma & 4 & $18.18 \%$ \\
\hline Facial nerve palsy & 1 & $4.54 \%$ \\
\hline Parotid fistula & 1 & $4.54 \%$ \\
\hline \multicolumn{2}{|c|}{ Post-Operative Complications } \\
\hline
\end{tabular}

\section{Malignant Lesions}

A total of 17 cases of malignant parotid tumours were there in our study of which the predominant type seen was mucoepidermoid carcinoma comprises of 7 cases. ${ }^{11}$

\begin{tabular}{|c|c|c|c|}
\hline Lesion & $\begin{array}{c}\text { No. of } \\
\text { Cases }\end{array}$ & Percentage & $\begin{array}{c}\text { Overall } \\
\text { Percentage }\end{array}$ \\
\hline $\begin{array}{c}\text { Mucoepidermoid } \\
\text { carcinoma } \\
\text { (Low grade) }\end{array}$ & 4 & $23.54 \%$ & $8.89 \%$ \\
\hline $\begin{array}{c}\text { Mucoepidermoid } \\
\text { carcinoma } \\
\text { (High grade) }\end{array}$ & 3 & $17.66 \%$ & $6.67 \%$ \\
\hline $\begin{array}{c}\text { Acinic cell } \\
\text { carcinoma }\end{array}$ & 1 & $5.88 \%$ & $2.22 \%$ \\
\hline $\begin{array}{c}\text { Adenoid cystic } \\
\text { carcinoma }\end{array}$ & 2 & $11.76 \%$ & $4.44 \%$ \\
\hline $\begin{array}{c}\text { Carcinoma ex } \\
\text { pleomorphic } \\
\text { adenoma }\end{array}$ & 2 & $11.76 \%$ & $4.44 \%$ \\
\hline Undifferentiated & 1 & $5.88 \%$ & $2.22 \%$ \\
\hline Lymphoma's(NHL) & 1 & $5.88 \%$ & $2.22 \%$ \\
\hline Adenocarcinoma & 2 & $11.76 \%$ & $4.44 \%$ \\
\hline \multicolumn{2}{|c|}{ Incidence } \\
\hline
\end{tabular}

\begin{tabular}{|c|c|c|c|}
\hline Sex & No. of Cases & Percentage & $\begin{array}{c}\text { Overall } \\
\text { Percentage }\end{array}$ \\
\hline Male & 8 & $50 \%$ & $17.78 \%$ \\
\hline Female & 8 & $50 \%$ & $17.78 \%$ \\
\hline \multicolumn{3}{|c|}{ Sex Incidence } \\
\hline
\end{tabular}

It was seen that the malignancies of the parotid affected men and women with equal incidence.

\begin{tabular}{|c|c|c|c|}
\hline Age & $\begin{array}{c}\text { No. of } \\
\text { Cases }\end{array}$ & Percentage & $\begin{array}{c}\text { Overall } \\
\text { Percentage }\end{array}$ \\
\hline $10-19$ & NIL & & \\
\hline $20-29$ & 2 & $12.5 \%$ & $4.44 \%$ \\
\hline $30-39$ & 3 & $12.5 \%$ & $4.44 \%$ \\
\hline $40-49$ & 1 & $6.25 \%$ & $2.22 \%$ \\
\hline $50-59$ & 2 & $12.5 \%$ & $4.44 \%$ \\
\hline $60-69$ & 5 & $31.25 \%$ & $11.1 \%$ \\
\hline $70-79$ & 4 & $25 \%$ & $8.88 \%$ \\
\hline \multicolumn{4}{|c|}{ Age Incidence } \\
\hline
\end{tabular}

The maximum incidence of malignancies was noted to be in the $7^{\text {th }}$ decade seen in $31.25 \%$ of malignancies followed by $8^{\text {th }}$ decade.

\begin{tabular}{|c|c|c|c|}
\hline Presentation & $\begin{array}{c}\text { No. of } \\
\text { Cases }\end{array}$ & Percentage & $\begin{array}{c}\text { Overall } \\
\text { Percentage }\end{array}$ \\
\hline $\begin{array}{c}\text { Swelling with } \\
\text { pain }\end{array}$ & 4 & $25 \%$ & $8.88 \%$ \\
\hline Painless swelling & 12 & $75 \%$ & $26.67 \%$ \\
\hline $\begin{array}{c}\text { Facial nerve } \\
\text { palsy }\end{array}$ & 6 & $36.5 \%$ & $13.33 \%$ \\
\hline Nodes & 8 & $50 \%$ & $17.78 \%$ \\
\hline Skin involvement & 4 & $25 \%$ & $8.88 \%$ \\
\hline $\begin{array}{c}\text { Deep lobe } \\
\text { involvement }\end{array}$ & 2 & $12.5 \%$ & $4.44 \%$ \\
\hline Discharge & 1 & $6.25 \%$ & $2.22 \%$ \\
\hline Recurrence & 6 & $37.5 \%$ & $13.33 \%$ \\
\hline $\begin{array}{c}\text { Mobility } \\
\text { restricted }\end{array}$ & 5 & $311.25 \%$ & $11.11 \%$ \\
\hline \multicolumn{4}{|c|}{ Presentation } \\
\hline
\end{tabular}

It was noted that half the cases of malignant parotid tumours presented with enlarged cervical nodes and a significant number of cases $(37.5 \%)$ had associated facial palsy.

\begin{tabular}{|c|c|}
\hline Lesion & $\begin{array}{c}\text { Total } \\
\text { No. of Positives }\end{array}$ \\
\hline Mucoepidermoid carcinoma & 6 \\
\hline Acinic cell carcinoma & 3 \\
\hline Adenoid cell carcinoma & Nil \\
\hline Adenocarcinoma & Nil \\
\hline Carcinoma pleomorphic adenoma & 2 \\
\hline Malignant cells & 3 \\
\hline \multicolumn{2}{|c|}{ FNAC } \\
\hline
\end{tabular}

With FNAC it was seen that 14 malignant tumours were detected. The final histopathology report showed that a total of 16 malignant parotid lesions were present.

It was seen that there were several errors in the detection of malignant lesions not only regarding the type of lesion that was detected, but in fact many were concluding a wrong result.

\section{Treatment Modalities}

Surgical modality was the mainstay treatment for most cases and the most commonly performed surgery was total parotidectomy. It comprised around $37.5 \%$. Also neck dissection was performed in $31.5 \%$ of the cases.

\begin{tabular}{|c|c|c|c|}
\hline Surgery & $\begin{array}{c}\text { No. of } \\
\text { Cases }\end{array}$ & Percentage & $\begin{array}{c}\text { Overall } \\
\text { Percentage }\end{array}$ \\
\hline $\begin{array}{c}\text { Total conservative } \\
\text { parotidectomy }\end{array}$ & 6 & $37.5 \%$ & $13.33 \%$ \\
\hline $\begin{array}{c}\text { Radical } \\
\text { parotidectomy }\end{array}$ & 4 & $25 \%$ & $8.89 \%$ \\
\hline $\begin{array}{c}\text { Completion } \\
\text { parotidectomy }\end{array}$ & 2 & $12.5 \%$ & $4.44 \%$ \\
\hline Neck dissection & 5 & $31.25 \%$ & $11.11 \%$ \\
\hline $\begin{array}{c}\text { Non-surgical } \\
\text { management }\end{array}$ & 4 & $25 \%$ & $8.89 \%$ \\
\hline \multicolumn{4}{|c}{ Treatment Modalities } \\
\hline
\end{tabular}

\section{Other Modalities}

Radiotherapy was used in almost all cases, either in the form of palliation or postoperatively as an adjuvant. Adjuvant radiotherapy was given in $62.5 \%$ of the patients with malignancies and as palliation in $31.25 \%$ of cases. Chemotherapy was given as adjuvant in one patient where the 
diagnosis was Non-Hodgkin's lymphoma (CHOP regimen) and as palliation in one case.

\section{Post-operative Complications}

The most common post-operative complication noted in this group of patients was facial palsy due to injury to the facial nerve seen in $50 \%$ of the cases. Also seroma formation was noted in $31.25 \%$ of the patients who underwent surgery.

One patient had vocal cord palsy due to the extensive dissection and resection of the infiltrative tumour.

\begin{tabular}{|c|c|c|c|}
\hline Complication & $\begin{array}{c}\text { No. of } \\
\text { Cases }\end{array}$ & Percentage & $\begin{array}{c}\text { Overall } \\
\text { Percentage }\end{array}$ \\
\hline $\begin{array}{c}\text { Facial nerve } \\
\text { palsy }\end{array}$ & 8 & $50 \%$ & $17.78 \%$ \\
\hline Seroma & 5 & $31.25 \%$ & $11.11 \%$ \\
\hline Flap necrosis & 2 & $12.5 \%$ & $4.44 \%$ \\
\hline Vocal cord palsy & 1 & $6.25 \%$ & $2.22 \%$ \\
\hline \multicolumn{3}{|c|}{ Post-operative Complications } \\
\hline
\end{tabular}

\section{DISCUSSION}

The comparative analysis of the study was made with other published studies and the following results were obtained.

\begin{tabular}{|c|c|c|c|}
\hline Institution & MMCH & $\begin{array}{c}\text { MD Anderson } \\
\text { Cancer Centre }\end{array}$ & Shaw Thai \\
\hline $\begin{array}{c}\text { Male: } \\
\text { Female }\end{array}$ & $1: 1.125$ & $1.01: 1$ & $1.03: 1$ \\
\hline Male & 20 & 77 & 53 \\
\hline Female & 25 & 75 & 55 \\
\hline \multicolumn{3}{|c|}{ Comparison of Sex Incidence } \\
\hline
\end{tabular}

\begin{tabular}{|c|c|c|c|c|}
\hline Centre & MMC & $\begin{array}{c}\text { MD } \\
\text { Anderson } \\
\text { Cancer } \\
\text { Centre }\end{array}$ & $\begin{array}{c}\text { Govt. } \\
\text { Medical } \\
\text { College } \\
\text { Chandigarh }\end{array}$ & $\begin{array}{l}\text { Italy } \\
\text { Piconi } \\
\text { et al . }\end{array}$ \\
\hline Specificity & $86 \%$ & & $99 \%$ \\
\hline Sensitivity & $82 \%$ & $97 \%$ & $81 \%$ \\
\hline PPV & $85 \%$ & $95 \%$ & $93 \%$ \\
\hline NPV & $86 \%$ & & $98 \%$ \\
\hline $\begin{array}{c}\text { Overall } \\
\text { Accuracy }\end{array}$ & $84 \%$ & $97 \%$ \\
\hline \multicolumn{3}{|c|}{ FNAC Comparison between our Institution } \\
\& Various Centres \\
\hline
\end{tabular}

\begin{tabular}{|c|c|c|c|}
\hline Centre & $\begin{array}{c}\text { Non- } \\
\text { Neoplastic } \\
\text { Lesions }\end{array}$ & $\begin{array}{c}\text { Benign } \\
\text { Tumours }\end{array}$ & $\begin{array}{c}\text { Malignant } \\
\text { Tumours }\end{array}$ \\
\hline MMCH & $15.55 \%$ & $48.89 \%$ & $35.56 \%$ \\
\hline $\begin{array}{c}\text { MD } \\
\text { Anderson }\end{array}$ & $7.14 \%$ & $43.51 \%$ & $49.35 \%$ \\
\hline $\begin{array}{c}\text { Shaw Tsai } \\
\text { et al }\end{array}$ & $13.89 \%$ & $77.81 \%$ & $8.3 \%$ \\
\hline \multicolumn{2}{|c|}{ Incidence of Various Lesions Among Institutions } \\
\hline
\end{tabular}

It was seen that among all the centres for most common benign and malignant lesions were corresponding with each other with pleomorphic adenoma and mucoepidermoid carcinoma respectively. ${ }^{12}$

\begin{tabular}{|c|c|c|c|c|c|c|}
\hline Centre & $\begin{array}{c}\text { Superficial } \\
\text { Parotidectomy }\end{array}$ & $\begin{array}{l}\text { Total Conservative } \\
\text { Parotidectomy }\end{array}$ & $\begin{array}{c}\text { Total Parotidectomy } \\
\text { Facial Nerve Resection }\end{array}$ & Radical & $\begin{array}{c}\text { Neck } \\
\text { Dissection }\end{array}$ & Others \\
\hline $\mathrm{MMCH}$ & $53.33 \%$ & $13.33 \%$ & & $8.89 \%$ & $11.11 \%$ & $13.33 \%$ \\
\hline $\begin{array}{l}\text { Nagarkar } \\
\text { et al }\end{array}$ & $79.17 \%$ & $12.5 \%$ & & $4.17 \%$ & $4.17 \%$ & $4.16 \%$ \\
\hline $\begin{array}{l}\text { Acar.A et } \\
\text { al }\end{array}$ & $74.4 \%$ & $16.28 \%$ & $6.98 \%$ & --- & $13.95 \%$ & $2.32 \%$ \\
\hline
\end{tabular}

In our study it was found that the other surgeries performed were completion parotidectomy, incision and drainage and excision biopsies which correspond with other studies. ${ }^{13}$

\section{Other Treatment Modalities}

Radiotherapy was used as a postoperative adjuvant management in most cases of malignant tumours. ${ }^{14,15}$

\begin{tabular}{|c|c|}
\hline \multicolumn{1}{|c|}{ Centre } & Post Op Radiotherapy \\
\hline MMCH & $62.5 \%$ \\
\hline Acar.A et al & $84.4 \%$ \\
\hline Nagarkar etal & $20 \%$ \\
\hline \multicolumn{2}{|c|}{ Other Treatment Modalities } \\
\hline
\end{tabular}

Post-Operative Complications

Most common complication was noted to be facial nerve palsy, transient or permanent.

\begin{tabular}{|l|c|c|c|c|}
\hline Post Op Complications & Facial Nerve Palsy & Seroma/Haematoma & Flap Necrosis/Infection & Parotid Fistula \\
\hline MMCH & $20 \%$ & $20 \%$ & $4.44 \%$ & $4.44 \%$ \\
\hline Acar.A et al & $30.1 \%$ & $5.8 \%$ & $4.6 \%$ & $3.4 \%$ \\
\hline Nagarkar et al & $29.17 \%$ & Nil & Nil & $8.33 \%$ \\
\hline \multicolumn{4}{|r|}{ Post-operative Complications } \\
\hline
\end{tabular}

\section{CONCLUSION}

The Analysis of the Data of the Study Conducted at our Institution provided us with the following Results:

1. Parotid lesions comprised of the most common salivary gland lesion in our hospital.
2. Amongst the various lesions, it was noted that benign tumours were the most common and the least common were non-neoplastic disorders.

3. The sex incidence showed a similar distribution among both males and females with the ratio being 1:1.02. 
4. The mean age of presentation was 49 years and it was seen that the $4^{\text {th }}$ decade and 7 th decades where the predominant age group for occurrence in case of benign and malignant tumours respectively.

5. The lesion which were predominant in the nonneoplastic, benign and malignant tumour groups where abscess, pleomorphic adenoma and mucoepidermoid carcinomas respectively. These were found to be consistent with the comparison made with world statistics.

6. FNAC correlated in a total of 39 out of 45 cases, i.e. $86.67 \%$ of the cases.

7. Patients presenting with facial nerve palsy was seen more among the malignant tumours.

8. Most commonly performed surgery was superficial parotidectomy. Completion parotidectomy was performed in 2 cases and both were malignant tumours.

9. Facial nerve palsy and seroma formation were the commonest complication noted post-operatively.

10. Radiotherapy was the most common non-surgical modality used and used more commonly in post-op.

\section{REFERENCES}

1. Kubacka M, Orendorz-Frączkowska K, Pazdro-Zastawny $\mathrm{K}$, et al. Epidemioloogical evaluation of salivary gland tumours in the wroclaw ENT department patients in the years 2001-2010. Otolaryhngol Pol 2013;67(1):30-3.

2. Borumandi F, George KS, Cascarini L, et al. Parotid sugery for benign tumours. Oral Maxillofac surg 2012;16(3):285-90.

3. Nepal A, Chettri ST, Joshi RR, et al. Primary salivary gland tumours in eastern Nepal tertiary care hospital. J Nepal Health Res Counc 2010;8(1):31-4.

4. Vedar LL, Kerrebijn JD, Smedts FM, et al. Diagnostic accuracy of fine needle aspiration cytology in warthin's tumour. Head and Neck 2010;32(12):1635-40.

5. Singh Nanda KD, Mehta A, Nanda J, et al. Fine-needle aspiration cytology: a relative tool in the diagnosis of salivary gland lesion. J Oral Pathol Med 2012;41(1):10612.
6. Gobic MB, Pedisić D, Bekafigo IS, et al. Fine needle aspiration cytology in the evaluation of parotid gland tumours. Coll Antropol 2010;34(2):345-8.

7. Javadi M, Asghari A, Hassannia F, et al. Value of fine needle aspiration cytology in the evaluation of parotid tumours. Indian J Otolaryngol Head and Neck Surg 2012;64(3):257-60.

8. Kara MI, Göze F, Ezirganli S, et al. Neoplasm of the salivary glands in a Turkish adult population. Med Oral Patol Oral Cir Bucal 2010;15(6):e880-5.

9. Nagarkar NM, Sandeep B, Arjun D, et al. Salivary gland tumours-our experience. Indian J otolaryngol Head and Neck Surg 2004;56(1):31-4.

10. Ali NS, Nawaz A, Rajput S, et al. Parotidectomy-a review of 112 patients treated in a teaching hospital in Pakistan. Asian Pacific J Cancer Prev 2010;11:1113-5.

11. Kizil Y, Aydil U, Ekinci O, et al. Salivary gland tumours in Turkey: demographic features and histopathological distribution in 510 paients. Indian J Otolaryngeal Head and Neck Surg 2013;65(1):112-20.

12. Ben Brahmin E, Ferchiou M, Khayat O, et al. Tumours of salivary glands-anatomical study and clinical epidemiology of a series 180 cases. Tunisie Med 2010;88(4):240-4.

13. Noh JM, Ahn YC, Nam H, et al. Treatment results of major salivary gland cancer by surgerywith or without postoperative radiation therapy. Clin Exp Otorhinolaryngol 2010;3(2):96-101.

14. Chan WH, Lee KW, Chiang FY, et al. Features of parotid gland diseases and surgical results in southern Taiwan. Kaohsiung J Med Sci 2010;26(9):483-92.

15. Shah K, Javed F, Alcock C, et al. Parotid cancer treatment with surgery followed by radiotherapy in oxford over 15 years. Ann R Coll Surg Engl 2011;93(3):218-22. 